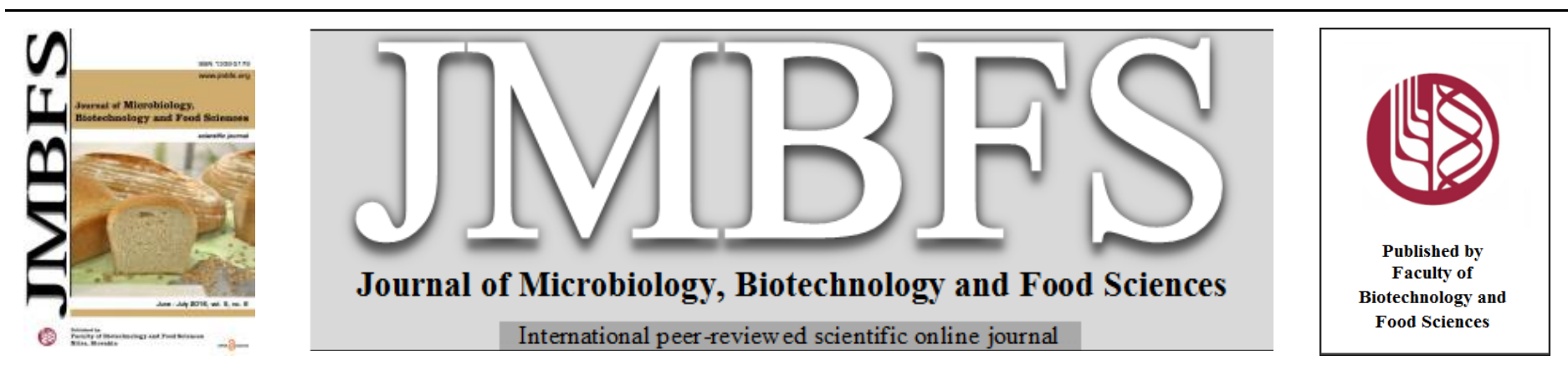

\title{
COST-EFFECTIVE PRODUCTION OF THE BIO-PLASTIC POLY-ß-HYDROXYBUTYRATE USING ACINETOBACTER BAUMANNII ISOLATE P39
}

\author{
Noha Salah Elsayed, Khaled Mohamed Aboshanab*, Mohammad Mohammad Aboulwafa, Nadia Abdelhaleem Hassouna
}

Address(es):

Department of Microbiology and Immunology, Faculty of Pharmacy, Ain Shams University, Al Khalifa Al Maamoun St., POB: 11566,Abbassia, Cairo, Egypt.

*Corresponding author: aboshanab2003@yahoo.com and aboshanab2012@pharma.asu.edu.eg

doi: 10.15414/jmbfs.2016.5.6.552-556

\section{ARTICLE INFO}

Received 15. 1.2015

Revised 26. 11. 2015

Accepted 13. 2. 2016

Published xx.xx.201x

Regular article

OPEN $\partial_{\text {Access }}$

\begin{abstract}
Being biodegradable and biocompatible natural polymer, poly- $\beta$-hydroxybutyrate (PHB) drew the attention of scientists to substitute synthetic plastics in our daily lives. However, its industrial production is hampered by its high cost. In this study, an extensive screening program was done to isolate bacteria with high PHB productivity from agricultural fields and develop a cost-effective PHB production. A promising bacterial isolate Acinetobacter baumannii P39 was recovered and identified using $16 \mathrm{~S}$ ribosomal gene sequencing. It produced $24 \%$ PHB per dry weight after $48 \mathrm{~h}$. Several experiments were conducted to optimize the composition of the culture medium and environmental factors for the selected isolate. Results revealed that $60 \%$ aeration, $28^{\circ} \mathrm{C}$ incubation temperature and initial $\mathrm{pH} 7.5$ showed the highest productivity. Besides, $0.7 \%$ corn oil and $0.1 \mathrm{~g} / \mathrm{L}$ peptone were the best carbon and nitrogen sources, respectively. Substituting glucose with corn oil led to a $23 \%$ reduction in total input cost and an estimate price for $1 \mathrm{~kg}$ PHB is 20.5 L.E. Strain improvement by UV mutation succeeded in improving PHB production by two fold in the selected mutant P39M2. Finally, this study valorizes usage of Acinetobacter isolate in PHB production in addition to solving the critical problem of high cost of production.
\end{abstract}

Keywords: Poly- $\beta$-hydroxybutyrate- bioplastic- Acinetobacter baumannii, biodegradable- biocompatible

\section{INTRODUCTION}

Biodegradable plastics are the ultimate solution for the everlasting problem of synthetic plastic wastes and its deleterious effect on environment (Poirier et al., 1995; Mecking, 2004). Biodegradable plastics, bioplastics, bacterial thermoplastic and green polymers all are names given to family of polyhydroxyalkanoates (Holmes, 1985; Poirier et al., 1995; Luengo et al., 2003). They have the same characteristics of synthetic plastics in addition to biodegradability and biocompatibility (Luckachan and Pillai, 2011).

Polyhydroxybutyrate (PHB) is the most abundant and well characterized member in polyhydroxyalkanoates (PHA) family. It has a widespread appearance in both Gram positive and Gram negative organisms (Senior et al., 1972). These bacteria produce polymer when subjected to unfavorable conditions of excess carbon sources with limitation of other sources such as nitrogen or phosphorus (Lee, 1996). The trend nowadays is industrial production of PHB from bacteria to substitute plastics in the market. However, high cost of bacterial PHB production hampered its industrial use in comparison to its rival. Several studies assumed that the reason behind such high cost is the productivity of microorganisms, substrates used and fermentation conditions (Nath et al., 2008). In our previous study, 251 bacterial isolates were recovered from agricultural fields where 53 isolates were PHB producers (Elsayed et al., 2013). By comparing the PHB production among positive isolates, Acinetobacter baumanii isolate $\mathrm{P} 39$ produced the highest PHB percentage per dry weight among tested Gram negative isolates. It produced $24 \%$ PHB per dry weight after 48 hours. It was identified by microscopical examination, cultural conditions and $16 \mathrm{~S}$ ribosomal RNA sequencing. The 16S rRNA sequences were submitted in GenBank with the following accession code KC876036. PHB production in Acinetobacter has not been extensively studied in literature. Rees and his coworkers studied PHB production in only three strains of Acinetobacter (Rees et al., 1992). Also Vierkant and his coworkers (1990) reported the presence of PHB in Acinetobacter species (Vierkant et al., 1990). Accordingly, the objective of our study was testing different environmental and nutritional factors affecting PHB production using Acinetobacter baumannii isolate P39 and strain improvement by physical and chemical mutations. The aim of this study was also to shine a new light on cost-effective PHB production using Acinetobacter baumannii.

\section{MATERIAL AND METHODS}

\section{Microorganisms}

Acinetobacter baumannii (accession code KC876036) is a PHB producing microorganism isolated from agricultural fields in Egypt. The organism was preserved in Luria Bertani (LB) medium supplemented with $20 \%$ glycerol at $20^{\circ} \mathrm{C}$.

\section{Culture Media}

In lab formulated basal mineral salts medium (MSM) and the newly formulated medium 39M were used in this study and their compositions are listed in Table 1. The ready-made culture media and media ingredients were obtained from Lab M (Topley house, England), Oxoid (USA) and Difco (Detroit, USA).

\section{Production of PHB}

The pre-culture was prepared by transferring a loopful from bacteria into $5 \mathrm{ml} \mathrm{LB}$ broth, incubated at $37^{\circ} \mathrm{C}$ and at $160 \mathrm{rpm}$ for 20 hours. The flasks were inoculated with the pre-culture at $5 \% \mathrm{v} / \mathrm{v}$ and incubated in a shaking incubator $(200 \mathrm{rpm})$ at $37^{\circ} \mathrm{C}$ for 48 hours. At different time intervals (time course experiments) or at the end the incubation period (other experiments), the broth was sampled to determine biomass and PHB concentration.

\section{Analytical Methods}

\section{Biomass determination}

Cellular growth was expressed in terms of dry cell weight which was calculated from the equation of a calibration curve constructed between optical density (OD $640 \mathrm{~nm}$ ) and dry cell weight of the tested isolate Acinetobacter baumannii isolate P39 (Elsayed et al., 2013). 
Table 1 Composition of MSM and newly formulated medium 83M used in PHB production

\begin{tabular}{|c|c|c|}
\hline Name of ingredient & Basal medium (MSM)* & $\begin{array}{l}\text { Newly formulated } \\
\text { medium }(39 M) *\end{array}$ \\
\hline Carbon source $(\mathrm{g} / \mathrm{L})$ & Glucose $(7.00 \mathrm{~g})$ & Corn oil $(7.0 \mathrm{ml})$ \\
\hline Nitrogen source $(\mathrm{g} / \mathrm{L})$ & $\begin{array}{l}\text { Ammonium chloride (0.10 } \\
\mathrm{g})\end{array}$ & peptone $(0.1 \mathrm{~g})$ \\
\hline Minerals $(\mathrm{g} / \mathrm{L})$ & $\begin{array}{c}\mathrm{MgSO} 4 \cdot 7 \mathrm{H} 2 \mathrm{O}(0.20 \mathrm{~g}) \\
\mathrm{CaCl} 2(0.01 \mathrm{~g}) \\
\text { Ferrous ammonium } \\
\text { sulphate }(0.06 \mathrm{~g}) \\
\text { Trace elements solution* }(1 \\
\mathrm{ml})\end{array}$ & No minerals \\
\hline Carbon source $(\mathrm{g} / \mathrm{L})$ & Glucose $(7.00 \mathrm{~g})$ & Corn oil $(7.0 \mathrm{ml})$ \\
\hline Nitrogen source $(g / L)$ & $\begin{array}{c}\text { Ammonium chloride }(0.10 \\
\mathrm{g})\end{array}$ & peptone $(0.1 \mathrm{~g})$ \\
\hline Minerals $(\mathrm{g} / \mathrm{L})$ & $\begin{array}{c}\text { MgSO4.7H2O }(0.20 \mathrm{~g}) \\
\mathrm{CaCl} 2(0.01 \mathrm{~g}) \\
\text { Ferrous ammonium } \\
\text { sulphate }(0.06 \mathrm{~g}) \\
\text { Trace elements solution* }(1\end{array}$ & No minerals \\
\hline
\end{tabular}

$\mathrm{ml})$

* Trace elements solution contains (amount/L) $\left(\mathrm{CoCl}_{2} .6 \mathrm{H}_{2} \mathrm{O}(0.20 \mathrm{~g}), \mathrm{H}_{3} \mathrm{~B}_{3}(0.30 \mathrm{~g})\right.$, $\mathrm{ZnSO}_{4} .7 \mathrm{H}_{2} \mathrm{O}(0.10 \mathrm{~g}), \mathrm{MnCl}_{2} .4 \mathrm{H}_{2} \mathrm{O}(30.0 \mathrm{mg}), \mathrm{NiCl}_{2}(10.0 \mathrm{mg}), \mathrm{CuSO}_{4} .5 \mathrm{H}_{2} \mathrm{O}(10.0 \mathrm{mg})$

* MSM and 39M media were sterilized by autoclaving. Glucose and trace elements solution were filter sterilized and were aseptically added to the autoclaved media with the indicated concentrations.

\section{PHB concentration determination}

For PHB extraction, about $1 \mathrm{ml}$ was taken from MSM growth culture in eppindorff tubes $(1.5 \mathrm{ml})$ previously washed with alcohol followed by hot chloroform (to remove plasticizers) (Law and Slepecky 1961).After centrifugation, the cell pellets were incubated with a sodium hypochlorite solution at $37^{\circ} \mathrm{C}$ for 1 hour at $160 \mathrm{rpm}$. After centrifugation, the pellets were washed with $1 \mathrm{ml}$ aliquot each of water, ethanol, and acetone, respectively. About $1 \mathrm{ml}$ hot chloroform was added to extract PHB. After that $10 \mathrm{ml}$ concentrated sulphuric acid $(98 \%)$ were added and the tubes were kept in a water bath at $100^{\circ} \mathrm{C}$ for $15 \mathrm{~min}$. The final solution was measured spectrophotometry at 235 $\mathrm{nm}$. A standard curve was constructed between crotonic acid concentrations and absorbance at $235 \mathrm{~nm}$ (Elsayed et al., 2013).

\section{Effect of different environmental and physiological conditions on PHB production}

For each factor the biomass, PHB concentration and its production percent per dry weight for the tested isolate were measured as previously mentioned. The factors investigated were inoculum size, initial $\mathrm{pH}$ and incubation temperature.

\section{Effect of aeration}

This was done by using flasks of equal sizes $(250 \mathrm{ml}$ each) with varying amoun of medium in each flask. MSM flasks with different medium volumes $(25,50$ and $100 \mathrm{ml})$ corresponding to $(90,80$ and $60 \%$ aeration, respectively) were prepared, inoculated and incubated.

\section{Effect of different media components}

a. Effect of replacement of glucose in MSM with other carbon sources. The tested carbon sources included sugars, sugar alcohol, oils and malt extract. The carbon sources showing promising PHB percentage per dry weight were tested at different concentrations.

b. Effect of replacement of ammonium chloride in MSM with other nitrogen sources. The nitrogen sources showing promising results were tested at different concentrations.

c. Effect of different multivalent minerals: The tested minerals are ferrous ammonium sulphate, calcium chloride, magnesium sulphate and trace elements. To study the effect of these minerals both on biomass and PHB productivity, five flasks each contained $20 \mathrm{ml}$ MSM were prepared as follows: One is MSM devoid of all minerals and each of the other four flasks contained one of the tested minerals. The used mineral concentration was the same as that used in MSM medium.

d. PHB production under combined selected pre-tested conditions: From the previously studied factors/ conditions that proved to be optimum for PHB production by the test isolate, a newly formulated medium was prepared and tested. In all cases, the selection criteria for the chosen factors/condition depended on high PHB percentage per dry weight and reasonable amount of biomass formation not less than $50 \%$ of the maximum biomass attained by the respective factor within the same tested category. Time course of PHB production was done for up to $72 \mathrm{~h}$ incubation period

\section{Induction of mutation using UV rays}

This was done by Direct-Plate Irradiation (Lin and Wang, 2001). A loopful of isolate from a nutrient agar slant was inoculated in LB broth for overnight at $37^{\circ} \mathrm{C}$ and $200 \mathrm{rpm}$. All UV irradiations were done in a custom-built UV chamber with a glass front (germicidal lamp $15 \mathrm{~W}$ UV lamp of $254 \mathrm{~nm}$ ). All the plates were incubated at $37^{\circ} \mathrm{C}$ for $24 \mathrm{~h}$ before scoring the number of colonies. This treatment resulted in $99.9 \%$ kill as determined by viable count of the survivors. The resultant colonies were collected for PHB production assessment.

\section{Induction of mutation using chemical mutagens}

This was done according to (Lopes et al., 2001) with minor modifications. Stock solutions of acriflavin and proflavin (each of $50 \mathrm{mg} / \mathrm{ml}$ ) were prepared in phosphate buffer $(50 \mathrm{mM}, \mathrm{pH} 7.5)$. Aliquots of $0.5 \mathrm{ml}$ from stock solutions of acriflavin and proflavin were separately added to a same volume of cell suspension of test isolate for 30 minutes. After centrifugation, about $200 \mu 1$ of the mutagen treated cells were surface inoculated onto nutrient agar plates then incubated at $37^{\circ} \mathrm{C}$ for 24 hours. The grown colonies were collected to measure PHB production.

\section{Economic analysis}

After evaluating the effect of newly formulated media on PHB production of the test isolate and its mutants, an economic analysis was done according to Baumol and Blinder (2005). This analysis was done to determine whether the change in culture conditions along with environmental conditions in newly formulated media affected the cost of production or not. For conducting this, the following parameters were calculated.

- $\quad$ Change in total cost $=$ Total cost in newly formulated medium-tota cost in basal medium where total cost included cost of both carbon and nitrogen sources in medium. The cost of included minerals was so small reaching a negligible value.

- $\quad$ Change in cost $=\underline{\mathrm{P}}_{2}-\underline{\mathrm{P}}_{1}$

$$
\begin{array}{lll}
\mathrm{P}_{1} & \bigcirc & \mathrm{P}_{1} \text { is the basal medium cost } \\
& \circ & \mathrm{P}_{2} \text { is the newly formulated medium cost. }
\end{array}
$$

\section{RESULTS}

As shown in figure (1), maximum PHB percentage per dry weight occurred at $60 \%$ aeration while maximum biomass in terms of dry weight occurred using $80 \%$ aeration. It was found also that $\mathrm{pH}$ of 7.5 was the best for maximum biomass and PHB percentage per dry weight. The best incubation temperature for maximum PHB percentage per dry weight without decreasing biomass was $28^{\circ} \mathrm{C}$. Maximum PHB percentage per dry weight was achieved using paraffin oil. On the other side, maximum PHB accumulation was achieved using corn oil where $181 \mu \mathrm{g} / \mathrm{ml}$ PHB was produced. After studying different concentrations of both agents, it was found that $0.7 \%$ corn oil is the best concentration to be used in further experiments (Figures 2 and 3).

After studying effect of different nitrogen sources on the tested parameters, peptone was the best (Figure 4). The concentration of $0.1 \mathrm{~g} / \mathrm{L}$ was chosen for further experiments. As shown in figure (6), maximum PHB production percentage per dry weight and biomass formation occurred using MSM free from all minerals. Individual testing of respective minerals showed variable effects on all of tested parameters. After implementing all of the optimum factors in the new medium 39M, Maximum PHB percentage per dry weight occurred after $48 \mathrm{~h}$ (28\%). Maximum biomass occurred after $24 \mathrm{~h}$ (Figure 7).

UV induced mutation improved the biomass to a great extent in collected two variants (39M2-M3) in comparison to wild organism. It also increased PHB productivity in one variant P39M2 by two fold (Data not shown). However it decreased PHB percentage per dry weight due to high biomass (Figure 8). On the other side chemical mutation decreased both of PHB productivity and percentage per dry weight in the collected variants. The outstanding effect of examining the PHB percentage per dry weight and biomass of selected mutant P39M2 using new medium $39 \mathrm{M}$ was achieving its highest values after only $24 \mathrm{~h}$ rather than 48 $h$ in case of wild organism (Figure 9). 


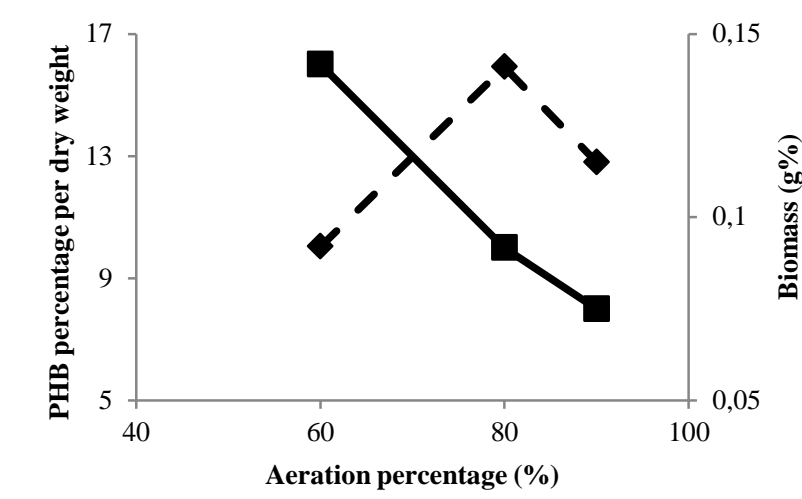

A $\longrightarrow$ PHB percentage per dry weight $\longrightarrow \bullet$ Biomass
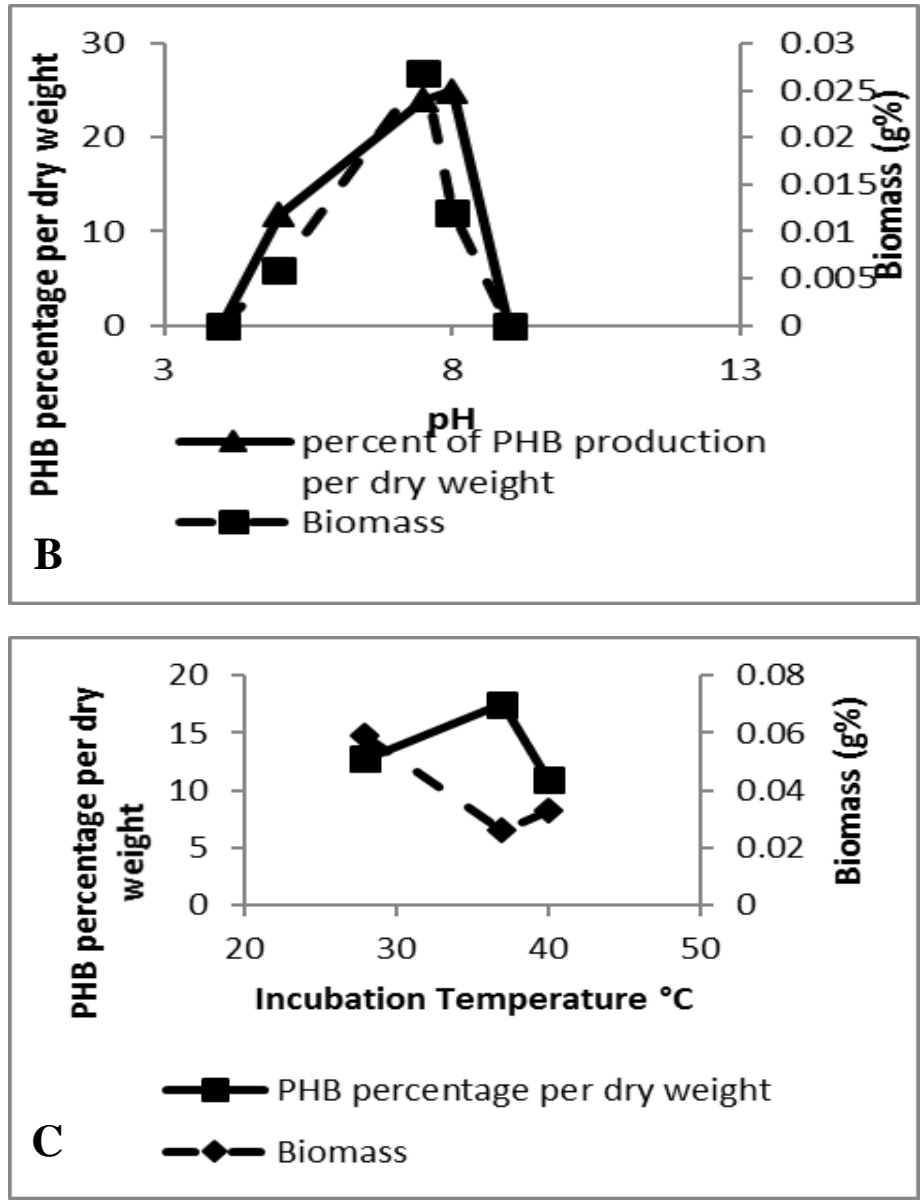

Figure 1 Effect of aeration (A), $\mathrm{pH}(\mathrm{B})$ and incubation temperature (C) on $\mathrm{PHB}$ percentage per dry weight and biomass of Acinetobacter baumannii isolate P39

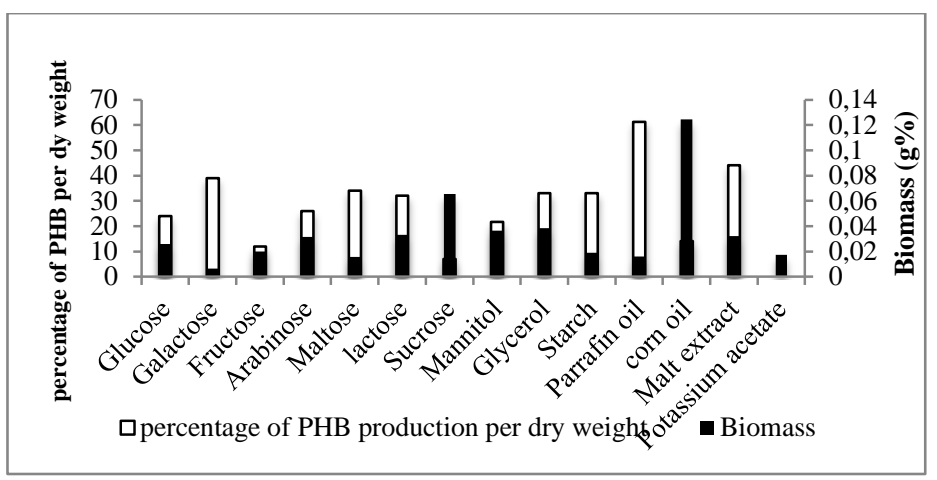

Figure 2 Effect of different carbon sources on PHB percentage per dry weight and biomass using Acinteobacter baumannii isolate P39

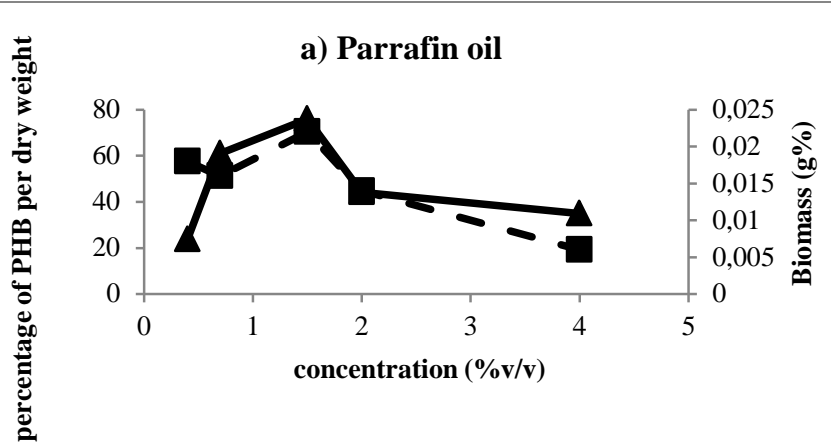

$\longrightarrow$ percentage of PHB production per dry weight $\boldsymbol{m}$ Biomass

b) corn oil

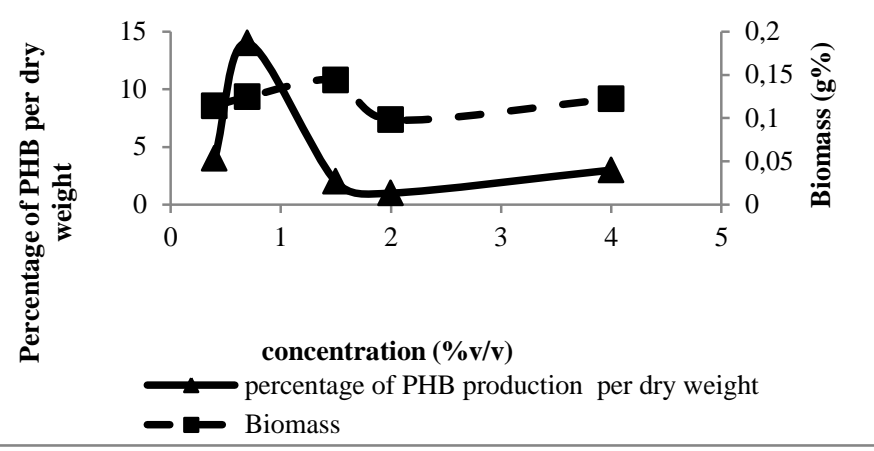

Figure 3 Effect of different concentrations of paraffin oil (a) and corn oil (b) on PHB production, biomass formation and PHB production percentage per dry weight of Acinetobacter baumannii isolate P39

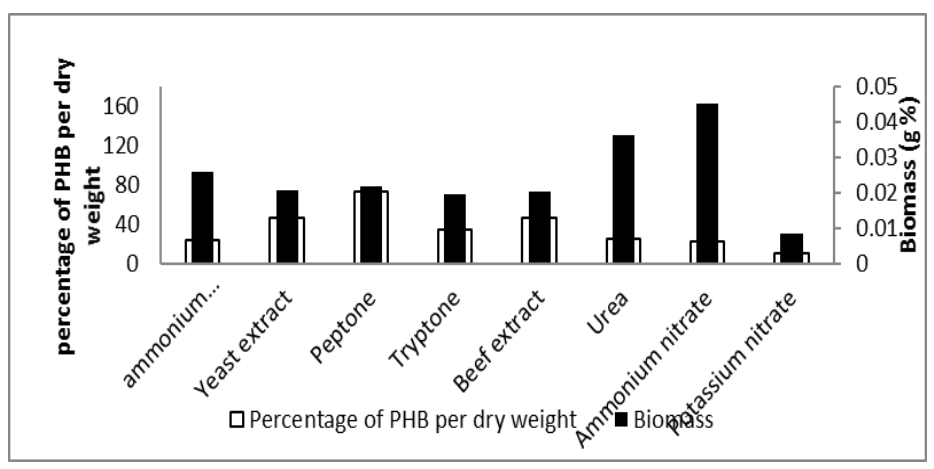

Figure 4 Effect of different nitrogen sources on PHB percentage per dry weight and biomass using Acinteobacter baumannii isolate P39

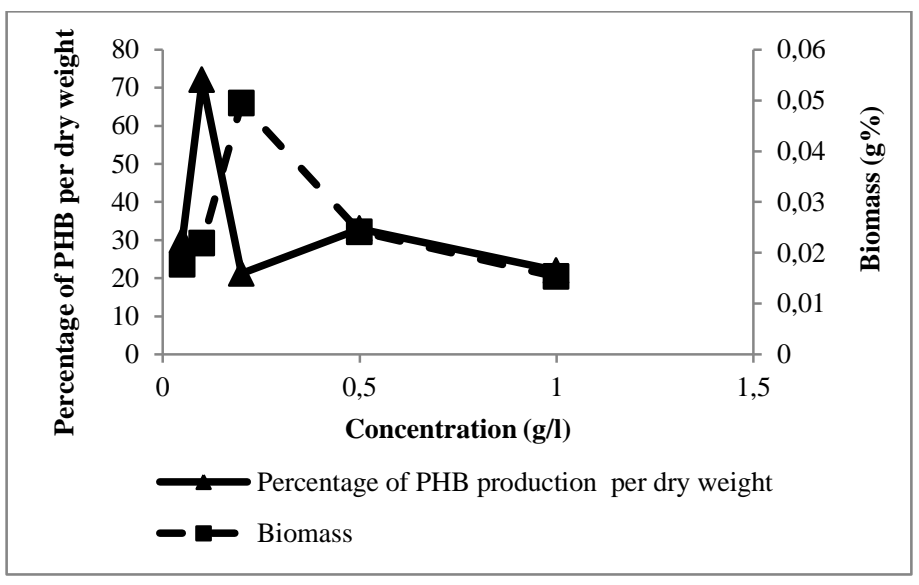

Figure 5 Effect of different concentrations of peptone on biomass formation and PHB production percentage per dry weight in Acinetobacter baumannii isolate P39 


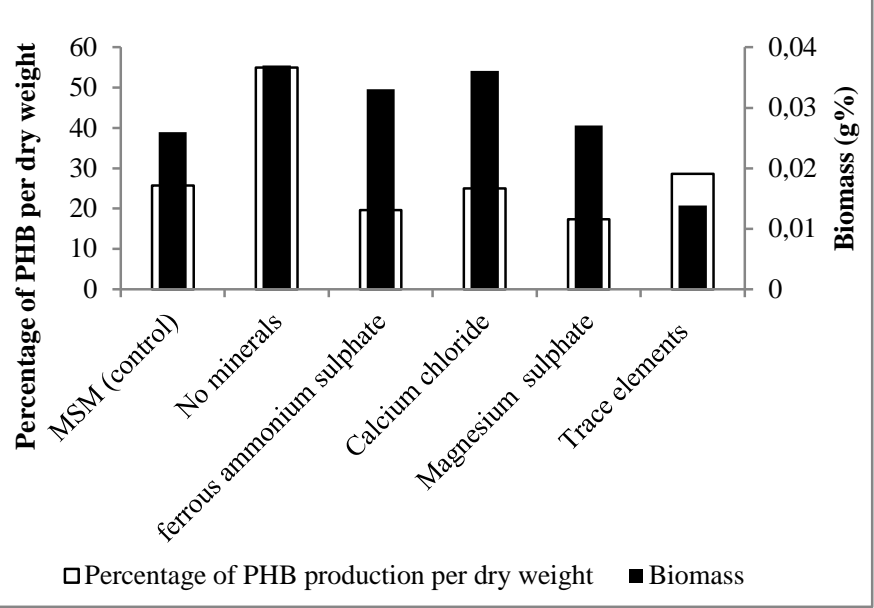

Figure 6 Effect of different minerals on PHB percentage per dry weight and biomass using Acinteobacter baumannii isolate P39

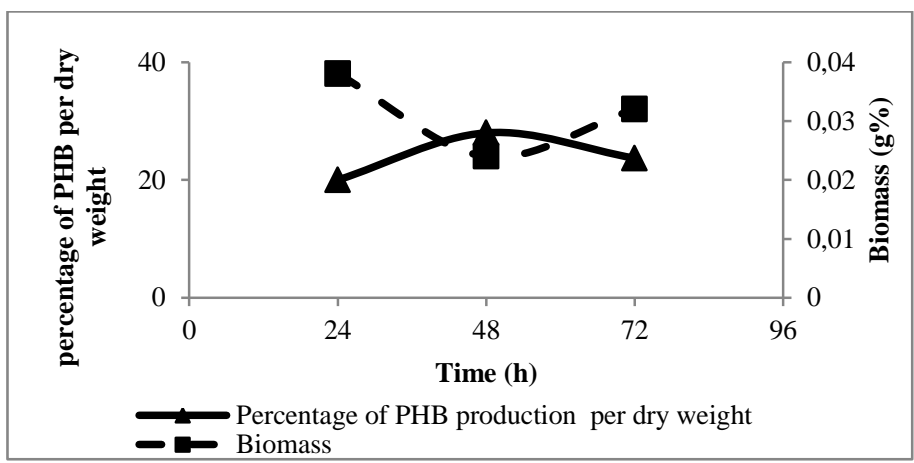

Figure 7 Time course of biomass formation and PHB production percentage per dry weight of Acinteobacter baumannii isolate P39 using newly formulated P39M

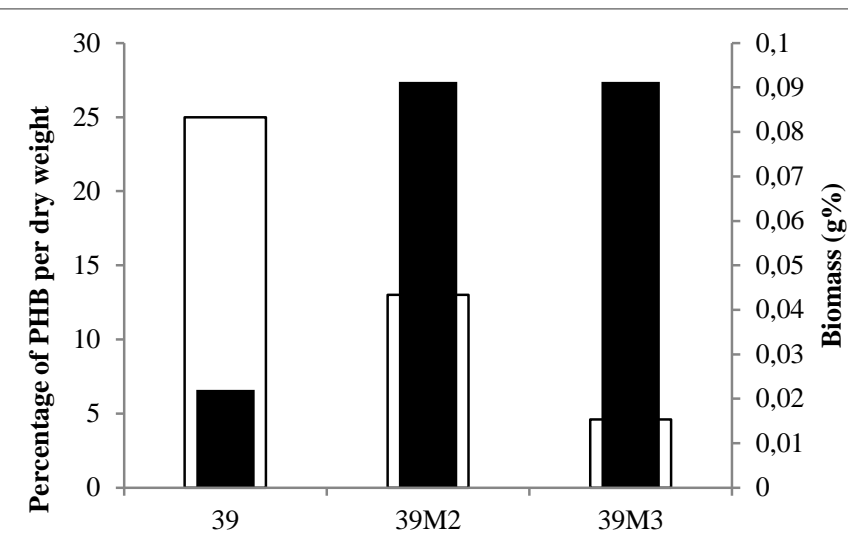

A $\square$ Percentage of PHB production per dry weight $\quad$ Biomass

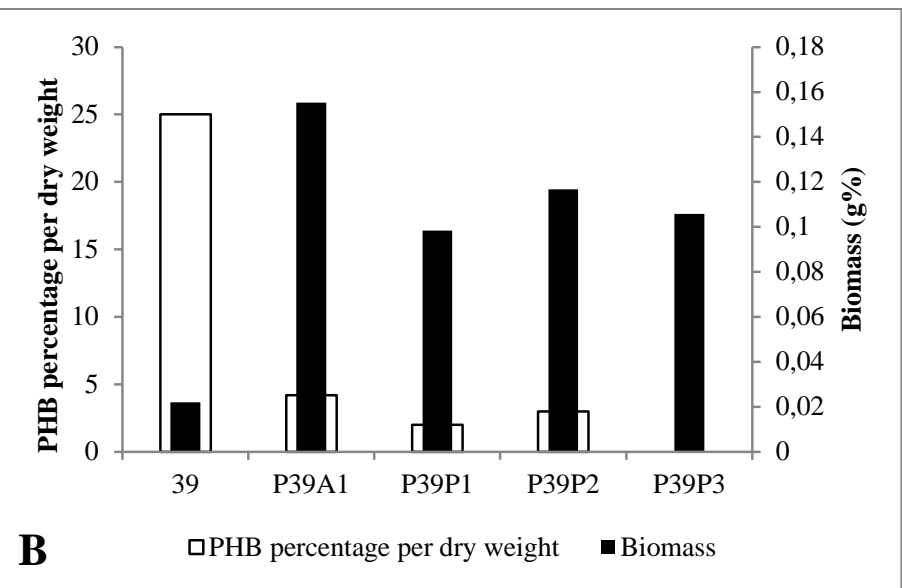

Figure 8 Effect of UV mutation (A) and chemical mutation (B) on biomass formation and PHB production percentage per dry weight of Acinteobacter baumannii isolate $\mathrm{P} 39$

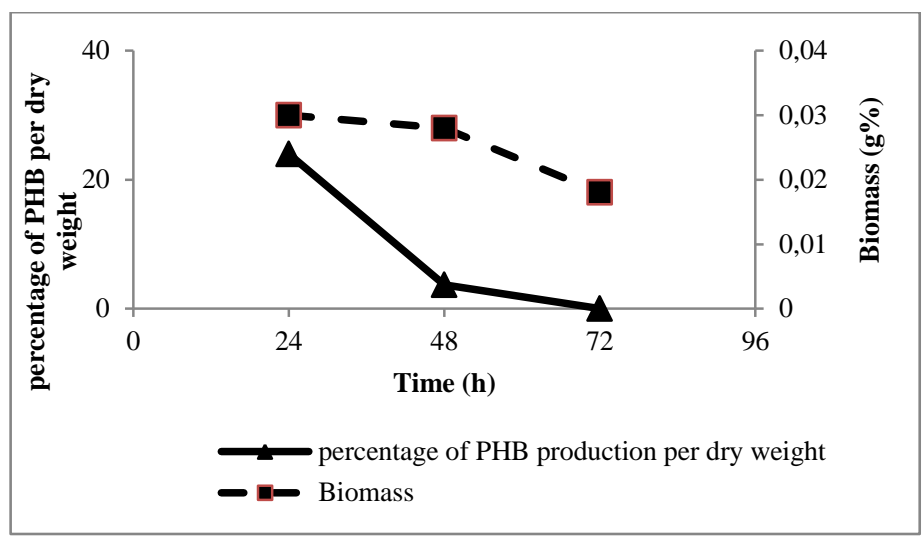

Figure 9 Time course of PHB production percentage per dry weight and biomass formation of the selected Acinetobacter baumannii recovered mutant P39M2 in medium 39M

\section{Economic analysis}

Table 2 The total cost of the basal medium in the tested isolate

\begin{tabular}{lcc}
\hline \multicolumn{1}{c}{ Ingredient } & Unit Price & Cost \\
\hline $\begin{array}{l}\text { Glucose } 7.0 \mathrm{~g} / \mathrm{L} \\
\text { Ammonium chloride }\end{array}$ & 12 L.E per $500 \mathrm{~g}$ & $0.1680 \mathrm{~L} . \mathrm{E}$ \\
$0.1 \mathrm{~g} / \mathrm{L}$ & $16 \mathrm{~L} . \mathrm{E}$ per $500 \mathrm{~g}$ & $0.0032 \mathrm{~L} . \mathrm{E}$ \\
\hline & Total cost $(\mathrm{P} 1)$ & $0.1712 \mathrm{~L} . \mathrm{E}$ \\
\hline
\end{tabular}

Table 3 The total cost of the newly formulated medium 39M

\begin{tabular}{ccc}
\hline Ingredient & Unit price & Cost \\
\hline Corn oil $7.0 \mathrm{ml} / \mathrm{L}$ & 16 L.E per $1 \mathrm{~L}$ & $0.1120 \mathrm{~L} . \mathrm{E}$ \\
Peptone $0.1 \mathrm{~g} / \mathrm{L}$ & 99 L.E per $500 \mathrm{~g}$ & $0.0198 \mathrm{~L} . \mathrm{E}$ \\
\hline & Total cost $(\mathrm{P} 2)$ & $0.1318 \mathrm{~L} . \mathrm{E}$ \\
\hline
\end{tabular}

Change in total cost

- $\quad$ Change in cost $=\underline{\mathrm{P}}_{2} \underline{\underline{\mathrm{P}_{1}}} \underline{ }^{*} 100$

\section{Price of produced PHB}

Acinteobacter baumanaii isolate P39 produced 78mg/L PHB (output) using newly formulated medium (39 M).

So estimated price of $1 \mathrm{Kg}$ PHB produced using Acinteobacterbaumanaii isolate P39and corn oil as carbon source should be not less than 20.5 L.E.

\section{DISCUSSION}

After testing the effect of environmental factors, it was obvious that some factors increase biomass only and others increase PHB production in particular. As a result we tend to choose the factor that increases PHB percentage per dry weight without decreasing biomass as latter is a perquisite for PHB production. According to $\mathrm{pH}$, it was found that $\mathrm{pH} 7.5$ was the best for maximum $\mathrm{PHB}$ production. This agreed with several studies (Sangkharak, and Prasertsan 2008; Liu et al., 2011 ). Moreover some studies stated that optimum temperatures for $\mathrm{PHB}$ production vary from $25^{\circ} \mathrm{C}$ to $37^{\circ} \mathrm{C}$ (Grothea et al., 1999). 
This agreed with our results where incubation temperature of $28^{\circ} \mathrm{C}$ was chosen. Pre-culture was done in LB broth as it is rich in nitrogen so it would improve protein synthesis and accordingly increase biomass (Ramadas et al., 2009). Best inoculum size was $5 \%$.

Excess carbon source in the culture medium with limited nitrogen source trigger bacteria to produce PHB to be used later as carbon source during starvation. Different categories of carbon sources were tested in this study: monosaccharaides; disaccharides; polysaccharides; sugar alcohols; oils and unrefined carbon sources. In our study, maximum PHB production was achieved using corn oil while maximum PHB percentage per dry weight was attained using paraffin oil. This agreed with several studies which stated that vegetable oils can be good carbon substrate for PHB production (Fukui and Doi, 1998; Budde $\boldsymbol{e}$ al., 2010 ) but, to the best of our knowledge, no other studies have mentioned the usage of paraffin oil in PHB production. This may be due to its inhibitory effect on biomass formation. After testing different concentrations of corn oil and paraffin oil, it was found that $0.7 \%$ corn oil gave maximum PHB percentage per dry weight without decreasing biomass. Vierkant and his coworkers (1990) studied PHB production in six strains of Acinteobacter. They found that glucose was optimum for three out of six strains of Acinetobacter and xylose for one and others did not respond to monosaccharaides (Vierkant et al., 1990). Rees and his coworkers (1992) also studied production of PHB in two Acinetobacter isolates using acetate salts, only one strain produced PHB using acetate while the other not ( Rees et al., 1992).

Brandl and his coworkers (1990) stated that usually, nitrogen-limiting conditions were chosen for the experimental work, because they are easily achieved by omitting ammonia from the growth medium (Brandl et al., 1990) Borah and his coworkers (2002) proposed that PHB synthesis efficiency depend on type of nitrogen source used (Borah et al., 2002). In our study the best nitrogen source was peptone. Page (1992) stated that peptone was the best nitrogen source for Azotobacter as it provides the cells with some amino acids so spare the need for de Novo amino acid synthesis (Page, 1992).Pal and his coworkers stated that peptone is the optimum nitrogen source (Pal et al., 2009).

By studying effect of minerals, it was found that minerals were not required for optimum PHB production. Some studies agreed with our results that absence of minerals was the optimum case (Sangkharak and Prasertsan, 2008 ).

After implementing all of optimum factors together in one newly formulated medium $39 \mathrm{M}$, only a slight increase in PHB percentage per dry weight was achieved. But the fascinating result was that a cost-effective production occurred Substituting glucose with cheap carbon source as corn oil led to a $23 \%$ reduction in total input cost and estimated price for the produced PHB will be 20.5 L.E. (tables $2 \& 3$ ) The current sale prices of PHB are between 3.1 and $4.4 \mathrm{USD} / \mathrm{kg}$, using glucose and/or sucrose as carbon sources (Naranjo et al., 2013). Such current sale price took in consideration all of production factors as machines and labor but our calculation was done for small scale production process only. In addition to that the selected mutant $39 \mathrm{M} 2$ produced $24 \%$ PHB percentage per dry weight after shorter incubation period ( 24 hours) in comparison to wild organism.

\section{CONCLUSION}

This study paves the way towards high PHB production using Acinetobacter baumannii isolate P39. Future studies will be directed towards large scale production of PHB followed by molecular characterization of genes involved in biosynthesis of PHB.

Acknowledgments: We would like to acknowledge department of Microbiology and Immunology, faculty of Pharmacy, Ain Shams University for giving us all facilities and equipment to accomplish this work. Also we thank Prof. Dr. Manal Metwally professor of economics in faculty of economics and political sciences in Cairo for her valuable assistance in economic analysis of PHB production in this research.

\section{REFERENCES}

BAUMOL, W. AND BLINDER, A. 2005. Economics: Principles and policy, Thomson higher education. Mason,

Ohio, 10th edition, Thomson South-Western, 796 pages

BORAH, B., THAKUR, P., NIGAM, J. 2002. The influence of nutritional and environmental conditions on the accumulation of poly-b-hydroxybutyrate in Bacillus mycoides RLJ B-017. Journal of Applied Microbiology, 92, 776783.http://dx.doi.org/10.1046/j.13652672.2002.01590.x

BRANDL, H., GROSS, R.A., LENZZ, R.W., FULLER. R 1990. Plastics from Bacteria and for Bacteria: Polyhydroxyalkanoates as Natural, Biocompatible, and Biodegradable Polyesters. Advances in Biochemical Engineering, Biotechnology, 41, 78-93. http://dx.doi.org/10.1007/bfb0010232

BUDDE, C., RIEDEL, S., HÜBNER, F., RISCH, S., POPOVIĆ, M., RHA,C. SINSKEY, A. 2010. Growth and polyhydroxybutyrate production by Ralstonia eutropha in emulsified plant oil medium. Applied Microbiology and Biotechnology, 89(5), 1611-1619.http://dx.doi.org/10.1007/s00253-011-3102-0 ELSAYED, N.S., ABOUlWAFA, M., ABOSHANAB, K., HASSOUNA, N 2013. PHB production in Azomonas, Acinteobacter and Bacillus species:
Isolation, screening and identification. Archives of Clinical Microbiology, 4(5) http://dx.doi.org/10.3823/271

FUKUI, T., DOI, Y. 1998. Efficient production of polyhydroxyalkanoates from plant oils by Alcaligenes eutrophus and its recombinant strain. Applied Microbiology and Biotechnology, 49, 333-336. http://dx.doi.org/10.1007/s002530051178

GROTHEA, E., MURRAY, M., CHISTIB, Y. 1999. Fermentation optimization for the production of poly( $\beta$-hydroxybutyric acid) microbial thermoplastic Enzyme and Microbial Technology, 25, 132-141. http://dx.doi.org/10.1016/s0141-0229(99)00023-x

HOLMES, A. 1985. Applications of PHB - a microbially produced biodegradable thermoplastic. Physical Technology, 16, 32-36. http://dx.doi.org/10.1088/03054624/16/1/305

LAW, J.H., SLEPECKY, R.A. 1961. Assay of poly-beta-hydroxybutyric acid Journal of Bacteriology, 82, 33-36.

LEE, S. 1996. Bacterial Polyhydroxyalkanoates. Biotechnology and Bioengineering, 49, 1-14. http://dx.doi.org/10.1002/(sici)10970290(19960105)49:1<1::aid-bit1>3.3.co;2-1

LIN, K., WANG, A. 2001. UV mutagenesis in Escherichia coli K-12: Cell survival and mutation frequency of the chromosomal genes lacZ, rpoB, ompF and ampA. Journal of Experimental Microbiology and Immunology, 1, 32-46.

LIU, Z., WANG, Y., HE, N., HUANG, J., ZHU, K., SHAO, W., WANG, H., YUANB, W., LI, Q. 2011. Optimization of polyhydroxybutyrate (PHB) production by excess activated sludge and microbial community analysis. Journal of Hazardous Materials, 185, 16.http://dx.doi.org/10.1016/j.jhazmat.2010.08.003

LOPES, B., HAMOUDA, A., FINDLAY, J., AMYES, S. 2011. Effect of frameshift mutagen acriflavine on control of resistance genes in Acinetobacter baumannii. Journal of Medical Microbiology, 60, 211-215. http://dx.doi.org/10.1099/jmm.0.025544-0

LUCKACHAN, G.E., PILLAI, C.K.S. 2011. Biodegradable Polymers- A Review on Recent Trends and Emerging Perspectives. Journal Polymer Environment, 19, 637-676. http://dx.doi.org/10.1007/s10924-011-0317-1 LUENGO, J., GARCIA, B., SANDOVAL, A., NAHARROY,G., OLIVERA, E. 2003. Bioplastics from microorganisms. Current Opinion in Microbiology, 6, 251-260.http://dx.doi.org/10.1016/s1369-5274(03)00040-7

MECKING, S. 2004. Nature or Petrochemistry?-Biologically Degradable Materials. Angewandte Chemie International Edition. 43, 1078 1085.http://dx.doi.org/10.1002/chin.200420290

NARANJO, J., POSADA, J., HIGUITA, J., CARDONA.C. 2013. Valorization of glycerol through the production of biopolymers: The PHB case using Bacillus megaterium $\quad$ Bioresource Technology, 133, 38 44.http://dx.doi.org/10.1016/j.biortech.2013.01.129

NATH, A., DIXIT, M., BANDIYA, A., CHAVDA, S., DESAI, A.J. 2008 Enhanced PHB production and scale up studies using cheese whey in fed batch culture of Methylobacterium sp. ZP24. Bioresource Technology, 99, 57495755.http://dx.doi.org/10.1016/j.biortech.2007.10.017

PAGE, W. 1992. Production of poly- $\beta$-hydroxybutyrate by Azotobactervinelandi UWD in media containing sugars and complex nitrogen sources. Applied Microbiology and Biotechnology, 38, 117 121.http://dx.doi.org/10.1007/bf00169430

PAL, A., PRABHU, A., KUMAR, A., RAJAGOPAL, B., DADHE, K. PONNAMMA, V., SHIVAKUMAR, S. 2009. Optimization of process parameters for maximum poly(-beta-)hydroxybutyrate (PHB) production by Bacillus thuringiensis IAM 12077. Pol Journal Microbiology, 58(2), 149154.http://dx.doi.org/10.1590/s1516-89132014000100009

POIRIER, Y., NAWRATH, C., SOMERVILLE,C. 1995. Production of polyhydroxyalkanoates, a family of biodegradable plastics and elastomers, in bacteria and plant. Biotechnology, 13, 142 150.http://dx.doi.org/10.1038/nbt0295-142

RAMADAS, N., SINGH, S., SOCCOL, S., PANDEY, A. 2009 Polyhydroxybutyrate Production using Agro-industrial Residue as Substrate by Bacillus sphaericus NCIM 5149. Brazllian Archives of Biology and Technology, 52(1), 17-23.http://dx.doi.org/10.1590/s1516-89132009000100003

REES, G., VASILIADIS, G., MAY, G., BAYLY, R. 1992. Production of polyfl-hydroxybutyrate in Acinetobacter sp, isolated from activated sludge. Applied $\begin{array}{llll}\text { Microbiology and } \quad \text { Biotechnology, } & 38,\end{array}$ 737.http://dx.doi.org/10.1007/bf00167136

SANGKHARAK, K., PRASERTSAN, P. 2008. Nutrient optimization for production of polyhydroxybutyrate from halotolerant photosynthetic bacteria cultivated under aerobic-dark condition. Electronic Journal of Biotechnology, 11(3), 1-12.http://dx.doi.org/10.2225/vol11-issue3-fulltext-2

SENIOR, P.J., BEECH, G.A., RITCHIET, G.A.F., DAWES, E.A 1972. The Role of Oxygen Limitation in the Formation of Poly- $\beta$-hydroxybutyrate during Batch and Continuous Culture of Azotobacter beijerinckii. Biochemistry Journal, 128, 1193-1201.http://dx.doi.org/10.1099/00221287-102-1-610

VIERKANT, M.A., MARTINA, D., STEWART, J. 1990. Poly-bhydroxybutyrate production in eight strains of the genus Acinetobacter. Canadian Journal of Microbiology, 36, 657-663.http://dx.doi.org/10.1139/m90-112 